\title{
Description of 13 Infants Born During October 2015-January 2016 With Congenital Zika Virus Infection Without Microcephaly at Birth — Brazil
}

\author{
Vanessa van der Linden, $\mathrm{MD}^{1 *}$; André Pessoa, MD²*; William Dobyns, $\mathrm{MD}^{3}$; A. James Barkovich, MD4; Hélio van der Linden Júnior, MD5; \\ Epitacio Leite Rolim Filho, MD, PhD ${ }^{1,6}$; Erlane Marques Ribeiro, MD, PhD²; Mariana de Carvalho Leal, MD, PhD 6,7; Pablo Picasso de Araújo \\ Coimbra, $\mathrm{MD}^{8}$; Maria de Fátima Viana Vasco Aragão, MD, PhD ${ }^{9,10}$; Islane Verçosa, $\mathrm{MD}^{11}$; Camila Ventura, MD, PhD ${ }^{12,13}$; Regina Coeli Ramos, MD ${ }^{12}$; \\ Danielle Di Cavalcanti Sousa Cruz, MD ${ }^{13}$; Marli Tenório Cordeiro, PhD ${ }^{14}$; Vivian Maria Ribeiro Mota ${ }^{15}$; Mary Dott, MD ${ }^{16}$; \\ Christina Hillard, MA ${ }^{17}$; Cynthia A. Moore, MA, PhD ${ }^{17}$
}

On November 22, 2016, this report was posted as an MMWR Early Release on the MMWR website (http://www.cdc.gov/mmwr).

Congenital Zika virus infection can cause microcephaly and severe brain abnormalities (1). Congenital Zika syndrome comprises a spectrum of clinical features (2); however, as is the case with most newly recognized teratogens, the earliest documented clinical presentation is expected to be the most severe. Initial descriptions of the effects of in utero Zika virus infection centered prominently on the finding of congenital microcephaly (3). To assess the possibility of clinical presentations that do not include congenital microcephaly, a retrospective assessment of 13 infants from the Brazilian states of Pernambuco and Ceará with normal head size at birth and laboratory evidence of congenital Zika virus infection was conducted. All infants had brain abnormalities on neuroimaging consistent with congenital Zika syndrome, including decreased brain volume, ventriculomegaly, subcortical calcifications, and cortical malformations. The earliest evaluation occurred on the second day of life. Among all infants, head growth was documented to have decelerated as early as 5 months of age, and 11 infants had microcephaly. These findings provide evidence that among infants with prenatal exposure to Zika virus, the absence of microcephaly at birth does not exclude congenital Zika virus infection or the presence of Zika-related brain and other abnormalities. These findings support the recommendation for comprehensive medical and developmental follow-up of infants exposed to Zika virus prenatally. Early neuroimaging might identify brain abnormalities related to congenital Zika infection even among infants with a normal head circumference (4).

Thirteen infants with laboratory evidence of congenital Zika virus infection and normal head size (less than or equal to 2 standard deviations [SD] below the mean for sex and gestational age) at birth (during October 2015-January 2016) are included in this report. The infants were evaluated by multidisciplinary teams at two referral centers in Brazil: the Rehabilitation Center of Association for Assistance of Disabled Children of Pernambuco, Recife, Pernambuco State, and the Infantil Albert Sabin Hospital, Fortaleza, Ceará State during the months of October 2015-October 2016.

\footnotetext{
* These authors contributed equally to this report.
}

Eleven of the infants came to clinical attention because their birth head circumference was below the level established by the Brazilian Ministry of Health as requiring further evaluation for possible congenital Zika virus infection (http://combateaedes. saude.gov.br/images/sala-de-situacao/Microcefalia-Protocolode-vigilancia-e-resposta-10mar2016-18h.pdf). This level was $33 \mathrm{~cm}$ before December 2, 2015, and $32 \mathrm{~cm}$ for gestational age $\geq 37$ weeks after that date; however, all of these infants had head circumferences at birth that did not exceed 2 SD below the mean for gestational age, and therefore did not meet the definition for microcephaly (more than 2 SD below the mean). These 11 infants were referred for neurologic evaluation and neuroimaging. The remaining two infants who had head circumferences in the normal range at birth were referred for neurologic evaluation at ages 5 and 7 months because of developmental concerns.

A standard form was used to collect demographic and clinical information, including whether the mothers recalled having had a rash during pregnancy. All information was obtained as part of the clinical protocol or as the result of clinical indication. Informed consent was obtained for the collection, use, and publication of clinical photographs of the infants.

Laboratory evidence of congenital Zika virus infection was defined as negative laboratory test results for five infectious causes of congenital microcephaly (toxoplasmosis, cytomegalovirus, rubella, syphilis and human immunodeficiency virus) and serologic evidence of Zika virus infection (a positive Zika virus-specific immunoglobulin $\mathrm{M}$ (IgM) capture enzymelinked immunosorbent assay (MAC-ELISA) result on infant cerebrospinal fluid [CSF] or serum). Conventional reverse transcription-polymerase chain reaction (RT-PCR) was performed for the detection of Zika virus and dengue virus RNA, and real-time RT-PCR was performed for chikungunya virus in the Recife location. Monoplex real-time RT-PCR for Zika virus was performed in the Fortaleza location $(5,6)$. Maternal testing for evidence of Zika virus infection was not available during the time of the 13 pregnancies.

For this report, microcephaly was defined as head circumference (HC) (also known as occipitofrontal circumference) more than 2 SD below the mean for gestational age and sex, according to the Fetal International and Newborn Growth Consortium 
for the 21st Century (INTERGROWTH-21st) for fetal and newborn growth (https://intergrowth21.tghn.org/) and the World Health Organization Child Growth Standards for infants (www.who.int/childgrowth/en/). Birth weight was evaluated and classified as appropriate, small, or large for gestational age and sex, also using INTERGROWTH-21st standards.

All infants had clinical neurologic and orthopedic evaluations, and brain imaging with computerized tomography (CT) scan without contrast, magnetic resonance imaging (MRI) without contrast, or both, and radiographs of the hips to identify congenital dislocation. In addition, all infants had clinical noninstrumental evaluation of dysphagia by a speech therapist, ophthalmologic examination with ophthalmoscopy assessment, and 11 of 13 infants had auditory evaluation by screening (auditory short latency brainstem evoked response [ABR] to click stimuli) and diagnostic tests (confirmatory frequency-specific $A B R$ with tone burst stimuli) using the routine recommended by Brazilian Heath Ministry and the American Academy of Pediatrics Joint Committee on Infant Hearing (7). Infants clinically suspected of having seizure activity had an electroencephalogram to confirm.

The case series included nine male infants and four female infants (Table 1). Eleven patients were born at term (37-41 weeks' gestation) and two were preterm (35 and 36 weeks' gestation). Six of 13 mothers described a cutaneous rash between the second and fifth months of pregnancy. All infants had birth weights that were appropriate for gestational age (i.e., within $2 \mathrm{SD}$ of the mean for sex and gestational age). Craniofacial disproportion was noted in six infants; three had redundant skin on the scalp at birth. Three infants had hip dysplasia, including one infant with arthrogryposis who had bilateral dislocated hips.

All infants had positive tests for Zika virus-specific IgM in either CSF only (nine infants), serum only (two infants) or CSF and serum (two infants). Seven CSF specimens were tested for Zika virus RNA by RT-PCR and all were negative; two of these infants also had negative RT-PCR testing in serum collected at the same time as CSF. RT-PCR testing results on the two serum-only specimens are pending. No Zika virus testing was performed on urine. Most infants (eight of 13) were tested within the first month of life; however, the date of testing of CSF for two infants is not known. Three infants were tested for Zika virus outside the neonatal period. Although identified at birth because of head size, one infant was not tested until age 4 months; two infants were tested at ages 5 months and 7 months when they were first evaluated because of developmental delay. One infant with both CSF and serum IgM testing positive at birth tested negative on serum re-testing at 6 months of age; another remained positive on re-testing at age 5 months.
HCs at birth ranged from 0.30 to $-2.00 \mathrm{SD}$ from the mean for gestational age and sex (Table 1). All infants showed a decrease in the rate of $\mathrm{HC}$ growth between birth and the time of the last examination. In 11 of 13 infants, postnatal microcephaly was diagnosed because of an HC measurement more than 2 SD below the mean for age and sex. Neuroimaging (CT scan in 13 infants and MRI in 10 infants) showed malformations of cortical development, which were most predominant anteriorly, and calcifications, predominantly in the subcortical region (especially in the transition area between the cortex and white matter). All neuroimaging showed evidence of decreased brain volume, with ventriculomegaly in all infants, and increased extra-axial CSF space in two of 13 infants (Table 2) (Figure).

Dysphagia was found on clinical evaluation in 10 of 13 infants. Seven infants had a diagnosis of epilepsy. Five infants had some degree of irritability, which improved by age 4 months. Most infants (12 of 13) had good visual interaction; one infant exhibited no eye contact. Three of 13 infants had chorioretinal abnormalities. All 11 infants tested had normal hearing evaluations. All infants had some degree of hypertonia; 12 of 13 had pyramidal and extrapyramidal signs with dystonic movement. One infant had spastic hemiparesis and another had bilateral hemiparesis, more severe on the left side. One infant with arthrogryposis was difficult to assess because of increased tone in some muscles and decreased in others. Nine of 13 infants had no voluntary movement of the hands and had a grasp reflex. Good head control was present in eight of 13 infants (supplemental material at https://stacks.cdc.gov/view/cdc/42517).

\section{Discussion}

Congenital microcephaly has been a hallmark of intrauterine infection with Zika virus. However, despite the absence of microcephaly at birth, the 13 infants in this report with laboratory evidence of Zika virus infection had brain abnormalities associated with congenital Zika syndrome, including ventriculomegaly and decreased brain volume, cortical malformations and subcortical calcifications, underscoring the importance of neuroimaging in evaluating these infants. In addition some infants had other structural or functional abnormalities that might have brought them to medical attention regardless of their head size; however, these findings did not occur more frequently in infants with the smallest HCs. Congenital Zika virus infection without microcephaly at birth previously has been reported (8), as has postnatal development of microcephaly in infants presumed to be infected congenitally (9). However, this is the first series of infants with laboratory evidence of congenital Zika virus infection documented to have poor head growth with microcephaly developing after birth.

Decreases in the rate of head growth postnatally in these infants was accompanied by significant neurologic dysfunction, 
TABLE 1. Clinical history and physical findings from 13 infants with congenital Zika infection without microcephaly at birth - Brazil, October 2015-October 2016

\begin{tabular}{|c|c|c|c|c|c|c|c|c|c|c|c|c|}
\hline $\begin{array}{l}\text { Patient } \\
\text { no. }\end{array}$ & Sex & $\begin{array}{c}\text { Gestational } \\
\text { age (wks) }\end{array}$ & $\begin{array}{l}\text { Birth } \\
\text { weight } \\
\text { (gm) }\end{array}$ & $\begin{array}{c}\text { Reported prenatal } \\
\text { ultrasound } \\
\text { abnormalities* }\end{array}$ & $\begin{array}{l}\text { Maternal } \\
\text { rash }\end{array}$ & $\begin{array}{c}\text { Infant Zika } \\
\text { virus IgM } \\
\text { antibody by } \\
\text { ELISA }\end{array}$ & $\begin{array}{l}\text { Birth HC } \\
(\mathrm{cm}) \text { and } \\
\left(\mathrm{SD}^{+}\right)\end{array}$ & $\begin{array}{c}\text { Age (mos) } \\
\text { at last } \\
\text { follow-up }\end{array}$ & $\begin{array}{l}\text { Follow-up } \\
\text { HC (cm) } \\
\left.\text { and (SD }{ }^{\S}\right)\end{array}$ & $\begin{array}{l}\text { Ocular } \\
\text { findings }\end{array}$ & $\begin{array}{l}\text { Craniofacial } \\
\text { disproportion } \\
\text { at birth** }\end{array}$ & $\begin{array}{c}\text { Arthrogryposis } \\
\text { or hip dysplasia } \\
\text { at birth }\end{array}$ \\
\hline 1 & $\mathrm{~F}$ & 35 & 2,570 & no & $3 \mathrm{mo}$. & CSF, serum + & $29.5(-1.72)$ & 11 & $39(-3.86)$ & no & yes & no \\
\hline 2 & $M$ & 38 & 3,125 & yes & $2 \mathrm{mo}$. & CSF + & $33.0(-0.40)$ & 10 & $41(-3.33)$ & yes & no & yes \\
\hline 3 & $M$ & 39 & 2,770 & no & none & CSF, serum + & $32.0(-1.63)$ & 11 & $43(-2.11)$ & no & no & no \\
\hline 4 & $M$ & 37 & 2,785 & yes & $2 \mathrm{mo}$. & CSF + & $31.0(-1.65)$ & 10 & $43(-1.98)$ & no & yes & no \\
\hline 5 & $\mathrm{~F}$ & 37 & 2,465 & yes & $5 \mathrm{mo}$. & $\mathrm{CSF}+$ & $31.0(-1.39)$ & 12 & $36(-6.18)$ & no & yes & no \\
\hline 6 & $M$ & 39 & 2,975 & no & $4 \mathrm{mo}$. & CSF + & $33.0(-0.78)$ & 11 & $42(-2.89)$ & no & no & no \\
\hline 7 & $M$ & 39 & 3,840 & no & none & $\mathrm{CSF}+$ & $33.0(-0.78)$ & 12 & $40(-4.68)$ & no & yes & yes \\
\hline 8 & $\mathrm{~F}$ & 41 & 2,955 & no & none & CSF + & $32.0(-1.95)$ & 9 & $39.5(-3.17)$ & no & no & yes \\
\hline 9 & $M$ & 39 & 3,155 & no & $3 \mathrm{mo}$. & $\mathrm{CSF}+$ & $33.5(-0.35)$ & 11 & $42.5(-2.50)$ & no & no & no \\
\hline 10 & $M$ & 40 & 3,100 & no & none & CSF + & $32.0(-2.00)$ & 10 & $40(-4.27)$ & yes & yes & no data \\
\hline 11 & $M$ & 38 & 2,965 & no & none & CSF + & $33.5(0.02)$ & 7 & $40(-2.98)$ & no & no & no data \\
\hline 12 & $\mathrm{~F}$ & 36 & 2,930 & no & none & serum + & $32.5(0.30)$ & 7 & $40.5(-1.35)$ & no & no & no \\
\hline 13 & $M$ & 40 & 2,990 & no & none & serum + & $33.0(-1.16)$ & 5 & $40(-2.12)$ & yes & yes & no \\
\hline
\end{tabular}

Abbreviations: $C S F=$ cerebrospinal fluid; ELISA = enzyme-linked immunosorbent assay; $F=$ female; $\mathrm{HC}=$ head circumference; IgM = immunoglobulin $\mathrm{M} ; \mathrm{M}=$ male; $\mathrm{SD}=$ standard deviation

* Abnormalities include brain calcifications (patient 2), microcephaly (patient 4), and decreased brain volume with ventriculomegaly (patient 5).

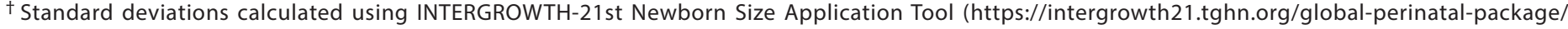
intergrowth-21st-comparison-application/).

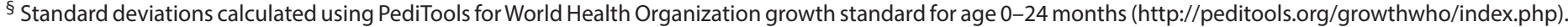

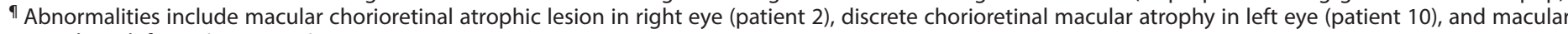
atrophy in left eye (patient 13).

** Abnormalities include redundant scalp (patients 5, 10, 13).

†† Abnormalities include arthrogryposis (patient 2), hip dysplasia (patients 2, 7,8) and diaphragmatic weakness (patient 2).

TABLE 2. Neuroimaging findings by computerized tomography (CT) and magnetic resonance (MR) for 13 infants with congenital Zika infection without microcephaly at birth - Brazil, October 2015-October 2016

\begin{tabular}{|c|c|c|c|c|c|c|c|c|c|}
\hline $\begin{array}{l}\text { Patient } \\
\text { no. }\end{array}$ & $\begin{array}{l}\text { Type of imaging* } \\
\text { (age performed) }\end{array}$ & $\begin{array}{l}\text { Decreased brain } \\
\text { volume }\end{array}$ & $\begin{array}{c}\text { Malformations } \\
\text { of cortical } \\
\text { development }\end{array}$ & $\begin{array}{c}\text { Most affected } \\
\text { lobes }^{\dagger}\end{array}$ & $\begin{array}{c}\text { Cerebellum or } \\
\text { brainstem } \\
\text { hypoplasia }\end{array}$ & $\begin{array}{c}\text { Corpus } \\
\text { callosum } \\
\text { hypoplasia }\end{array}$ & $\begin{array}{c}\text { Ventriculo- } \\
\text { megaly }\end{array}$ & $\begin{array}{c}\text { Increased } \\
\text { extra-axial CSF } \\
\text { space }\end{array}$ & Calcifications $^{\S}$ \\
\hline 1 & $\begin{array}{l}\text { CT (1 mo.) } \\
\text { MR (4 mo.) }\end{array}$ & yes & yes & right anterior & yes & yes & yes & no & $\begin{array}{c}\text { subcortical and } \\
\text { basal ganglia }\end{array}$ \\
\hline 2 & $\begin{array}{l}\text { CT (1 wk.) } \\
\text { MR (2 mo.) }\end{array}$ & yes & yes & bilateral diffuse & yes & no & yes & no & $\begin{array}{l}\text { subcortical, } \\
\text { basal ganglia }\end{array}$ \\
\hline 3 & $\begin{array}{l}\text { CT (2 days) } \\
\text { MR (1 wk.) }\end{array}$ & yes $^{\dagger}$ & yes $^{\dagger}$ & right diffuse & no & yes & yes & no & subcortical \\
\hline 4 & $\begin{array}{l}\text { CT (1 day) } \\
\text { MR (7.5 mo.) }\end{array}$ & yes & yes & unknown & yes & unknown & yes & no & $\begin{array}{c}\text { subcortical and } \\
\text { basal ganglia }\end{array}$ \\
\hline 5 & $\begin{array}{l}\text { CT (3 days) } \\
\text { MR ( } 12 \text { mo.) }\end{array}$ & yes & yes & bilateral diffuse & yes & yes & yes & yes & $\begin{array}{c}\text { subcortical and } \\
\text { basal ganglia }\end{array}$ \\
\hline 6 & $\begin{array}{l}\text { CT (3 days) } \\
\text { MR (3.5 mo.) }\end{array}$ & no & yes $^{\dagger}$ & bilateral anterior & no & yes & yes & no & subcortical \\
\hline 7 & $\begin{array}{l}\text { CT (2 wks.) } \\
\text { MR (9 mo.) }\end{array}$ & yes & yes & bilateral diffuse & no & yes & yes & yes & subcortical \\
\hline 8 & CT (2 mo.) & yes & yes & unknown & no & yes & yes & no & $\begin{array}{c}\text { subcortical and } \\
\text { basal ganglia }\end{array}$ \\
\hline 9 & $\begin{array}{l}\text { CT (3 days) } \\
\text { MR (6 mo.) }\end{array}$ & yes & yes & bilateral anterior & no & no & no & no & subcortical \\
\hline 10 & СТ (3 mo.) & yes & yes & bilateral diffuse & no & not assessed & yes & no & basal ganglia \\
\hline 11 & CT (7 mo.) & yes & yes & bilateral diffuse & no & not assessed & yes & yes & subcortical \\
\hline 12 & $\begin{array}{l}\text { CT (1 mo.) } \\
\text { MR (9 mo.) }\end{array}$ & yes & yes & bilateral diffuse & no & yes & no & no & subcortical \\
\hline 13 & $\begin{array}{l}\text { CT (2 mo.) } \\
\text { MR (11 mo.) }\end{array}$ & yes & yes & bilateral diffuse & no & yes & yes & no & subcortical \\
\hline
\end{tabular}

Abbreviations: $C T$ = computed tomography; $M R=$ magnetic resonance.

* Findings for infants evaluated both by CT and MR are consistent unless otherwise noted.

† Based on MR.

$\S$ Based on CT. 
FIGURE. Clinical photographs and magnetic resonance (MR) and computed tomography (CT) images of two infants with congenital Zika syndrome* Brazil, October 2015-October 2016

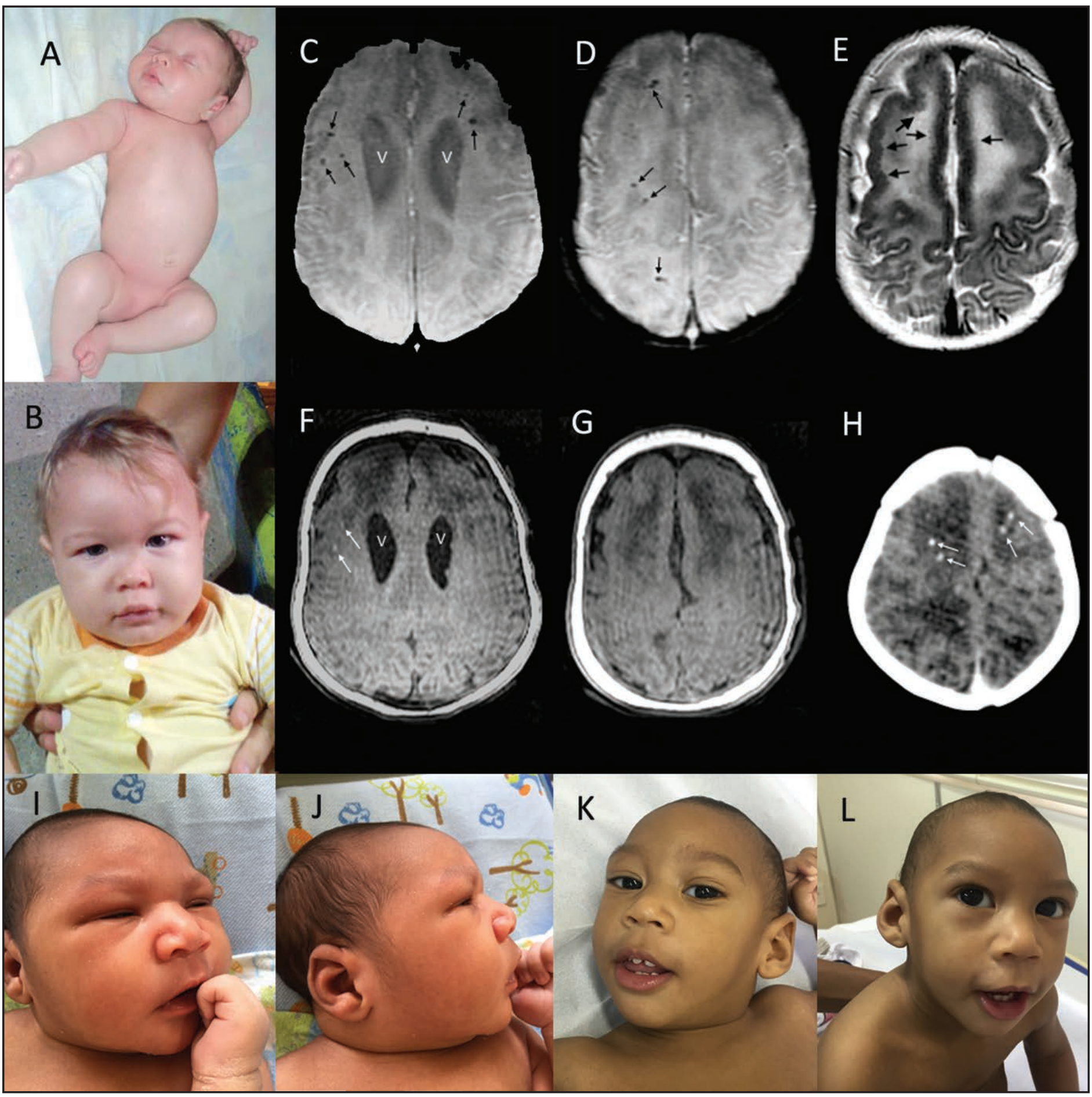

* A. A newborn (patient 6 in Table 2) with no discernable anomalies including no craniofacial disproportion and normal limbs. B. Same infant at 11 months with head circumference at almost 3 standard deviations below the mean but no apparent craniofacial anomalies. C.D. Axial susceptibility-weighted images at 3.5 months show enlarged lateral ventricles (V) and multiple calcifications (small black arrows). E. T2-weighted image shows thickened frontal cortex with reduced frontal sulcation. Slight irregularities of the inner cortical surfaces of the frontal lobes (black arrows), consistent with polymicrogyria. F.G. On T1-weighted images the ventricles (V) are slightly more apparent and two of the larger calcifications (white arrows) are seen as areas of hyperintensity. H. Noncontrast axial CT from an earlier scan at 3 days shows streak artifacts from patient motion and multiple frontal white matter calcifications (white arrows). I.J. Newborn (patient 7 in Table 2) with slightly depressed frontal regions and sloping forehead noted in I. but less evident in J., the lateral view. K.L. At 12 months, photographs show clear microcephaly but also an engaged infant with good eye contact. 
including hypertonia and hemiparesis, dyskinesia/dystonia, dysphagia, epilepsy, and persistence of primitive reflexes. Although these neurologic findings are consistent with previous reports of infants with congenital microcephaly who had prenatal exposure to Zika virus (2), infants who did not have microcephaly at birth showed better social interaction (i.e., they made and held eye contact and had a social smile). However, more than $60 \%$ of infants in this series had epilepsy (likely related to the cortical malformations), and all had significant motor disabilities consistent with mixed cerebral palsy (10). The infants were too young to be adequately assessed for cognitive deficits.

Among the six mothers who reported a rash, four reported rash in the first trimester and two in the second trimester. Therefore, among these mothers, early occurrence of the presumed infection during pregnancy did not result in the most severe congenital Zika phenotype (i.e., microcephaly at birth). Only three infants were reported to have a history of prenatal ultrasound abnormalities consistent with congenital Zika virus infection.

The pathogenesis of postnatal microcephaly from congenital Zika virus infections is not known. The decrease in head growth might be the consequence of earlier in utero destruction of neuroprogenitor or other neural cells, persistent inflammatory response-associated molecules, or continued infection of neural cells. The last seems less likely given the negative Zika virus RT-PCR results in all seven tested CSF samples.

The findings in this report are subject to at least four limitations. First, birth HC measurements were recorded with a resolution of $0.5 \mathrm{~cm}$ (in contrast to the customary $0.1 \mathrm{~cm}$ ), which likely resulted in either overestimate or underestimate of the measure in some infants. Two infants had a birth HC that was at or slightly less than 2 SD below the mean, and their HCs could have been misclassified as falling within the normal range. In addition, calculations of SD can vary among the published growth standards for HC. Second, Zika IgM testing was not confirmed by plaque reduction neutralization testing; therefore, infants could have been misclassified because of cross-reactivity with other flaviviruses or nonspecific reactivity within the ELISA. Third, based on this clinical series alone, the birth prevalence of congenital Zika syndrome without microcephaly in the population cannot be estimated. Finally, because serial neuroimaging in an infant is not clinically indicated, progressive changes such as the rate of brain volume loss cannot be assessed.

Additional information is needed to fully describe the clinical spectrum of findings associated with congenital Zika virus infection. This report documents that microcephaly at birth is

\section{Summary}

What is already known about this topic?

Congenital Zika virus infection can cause microcephaly and severe brain abnormalities. As more information about the associated clinical syndrome becomes available, the phenotype is expanding to include other, sometimes less severe features, such as brain abnormalities without congenital microcephaly.

What is added by this report?

Although infants with congenital Zika virus infection who have a normal head size have been described in large series, sufficient description of the features of congenital Zika syndrome in these infants has not been available. This report of a series of 13 infants with laboratory evidence of congenital Zika virus infection with normal head size at birth includes the findings from extensive imaging, neurologic, ophthalmologic, auditory, and orthopedic examinations. Follow-up of these infants has shown that for most, head growth deceleration occurs to the point of microcephaly after birth and significant neurologic sequelae are evident.

What are the implications for public health practice?

Additional information is needed to fully describe the spectrum of findings associated with congenital Zika virus infection; however, microcephaly might not be evident at birth but can develop after birth in infants with underlying brain abnormalities. These findings underscore the importance of early neuroimaging for infants exposed to Zika virus prenatally.

not an essential hallmark of congenital Zika syndrome. Infants with normal $\mathrm{HC}$ at birth have brain and other abnormalities associated with congenital Zika syndrome and might develop microcephaly after birth. These findings demonstrate the importance of early neuroimaging for infants exposed to Zika virus prenatally and the need for comprehensive medical and developmental follow-up.

\footnotetext{
${ }^{1}$ Association for Assistance of Disabled Children, Recife, Pernambuco, Brazil; ${ }^{2}$ Hospital Infantil Albert Sabin, Fortaleza, Ceará, Brazil; ${ }^{3}$ University of Washington and Seattle Children's Research Institute, Seattle; ${ }^{4}$ University of California-San Francisco; ${ }^{5}$ Dr. Henrique Santillo Rehabilitation Center, Goiania, Brazil; ${ }^{6}$ Federal University of Pernambuco, Recife, Pernambuco, Brazil; ${ }^{7}$ Agamenon Magalhães Hospital (HAM), Recife, Pernambuco Brazil; ${ }^{8}$ Uniclinic Diagnóstico por Imagem, Fortaleza, Brazil; ${ }^{9}$ Centro Diagnóstico Multimagem, Recife, Pernambuco, Brazil; ${ }^{10}$ Mauricio de Nassau University, Recife, Pernambuco, Brazil; ${ }^{11}$ Caviver Clinical, Fortaleza, Ceará, Brazil; ${ }^{12}$ Altino Ventura Foundation, Recife, Pernambuco, Brazil; ${ }^{13}$ Pernambuco's Eye Hospital, Recife, Pernambuco, Brazil; ${ }^{12}$ Oswaldo Cruz University Hospital, Recife, Pernambuco, Brazil; ${ }^{13}$ Professor Fernando Figueira Integral Medicine Institute, Recife, Pernambuco, Brazil; ${ }^{14}$ Centro de Pesquisas Aggeu Magalhães-Fiocruz, Recife, Pernambuco, Brazil; ${ }^{15}$ University of Fortaleza, Fortaleza, Brazil; ${ }^{16}$ Center for Surveillance, Epidemiology and Laboratory Services, CDC; ${ }^{17}$ National Center on Birth Defects and Developmental Disabilities, CDC.
}

Corresponding author: Cynthia A. Moore, zikamch@cdc.gov; 770-488-7100. 


\section{References}

1. de Araújo TV, Rodrigues LC, de Alencar Ximenes RA, et al. Association between Zika virus infection and microcephaly in Brazil, January to May, 2016: preliminary report of a case-control study. Lancet Infect Dis 2016. Epub September 15, 2016.

2. Moore CA, Staples JE, Dobyns WB, et al. Characterizing the pattern of anomalies in congenital Zika syndrome for pediatric clinicians. JAMA Pediatr 2016. http://dx.doi.org/10.1001/jamapediatrics.2016.3982

3. Schuler-Faccini L, Ribeiro EM, Feitosa IM, et al. Possible association between Zika virus infection and microcephaly-Brazil, 2015. MMWR Morb Mortal Wkly Rep 2016;65:59-62. http://dx.doi.org/10.15585/ mmwr.mm6503e2

4. Russell K, Oliver SE, Lewis L, et al. Update: interim guidance for the evaluation and management of infants with possible congenital Zika virus infection-United States, August 2016. MMWR Morb Mortal Wkly Rep 2016;65:870-8. http://dx.doi.org/10.15585/mmwr.mm6533e2

5. Lanciotti RS, Calisher CH, Gubler DJ, Chang GJ, Vorndam AV. Rapid detection and typing of dengue viruses from clinical samples by using reverse transcriptase-polymerase chain reaction. J Clin Microbiol 1992;30:545-51.
6. Lanciotti RS, Kosoy OL, Laven JJ, et al. Genetic and serologic properties of Zika virus associated with an epidemic, Yap State, Micronesia, 2007. Emerg Infect Dis 2008;14:1232-9. http://dx.doi.org/10.3201/ eid1408.080287

7. American Academy of Pediatrics, Joint Committee on Infant Hearing. Year 2007 position statement: principles and guidelines for early hearing detection and intervention programs. Pediatrics 2007;120:898-921. http://dx.doi.org/10.1542/peds.2007-2333

8. França GV, Schuler-Faccini L, Oliveira WK, et al. Congenital Zika virus syndrome in Brazil: a case series of the first 1501 livebirths with complete investigation. Lancet 2016;388:891-7. http://dx.doi.org/10.1016/ S0140-6736(16)30902-3

9. Moura da Silva AA, Ganz JSS, Sousa PD, et al. Early growth and neurologic outcomes of infants with probable congenital Zika virus syndrome. Emerg Infect Dis 2016;22:1953-6. http://dx.doi. org/10.3201/eid2211.160956

10. Wimalasundera N, Stevenson VL. Cerebral palsy. Pract Neurol 2016;16:184-94. http://dx.doi.org/10.1136/practneurol-2015-001184 